\title{
Fatal encephalitis due to the scuticociliate Uronema nigricans in sea-caged, southern bluefin tuna Thunnus maccoyii
}

\author{
B. L. Munday ${ }^{1, *}$, P. J. O'Donoghue ${ }^{2}$, M. Watts ${ }^{1}$, K. Rough $^{3}$, T. Hawkesford ${ }^{1}$ \\ ${ }^{1}$ Department of Aquaculture, University of Tasmania, PO Box 1214, Launceston, Tasmania 7250, Australia \\ ${ }^{2}$ Department of Parasitology, University of Queensland, Queensland 4072, Australia \\ ${ }^{3}$ Tuna Boat Owners Association of Australia, PO Box 1146, Port Lincoln, South Australia 5606, Australia
}

\begin{abstract}
A syndrome characterized by atypical swimming behaviour followed by rapid death was first reported in captive southern bluefin tuna Thunnus maccoyii (Castelnau) in the winter of 1993. The cause of this behaviour was found to be a parasitic encephalitis due to the scuticociliate Uronema nigricans (Mueller). Based on parasitological and histological findings, it is proposed that the parasites initially colonise the olfactory rosettes and then ascend the olfactory nerves to eventually invade the brain. Possible epidemiological factors involved in the pathogenesis of the disease include water temperature $\left(<18^{\circ} \mathrm{C}\right)$ and the immune status of the fish.
\end{abstract}

KEY WORDS: Southern bluefin tuna - Thunnus maccoyii - Scuticociliate - Uronema nigricans Encephalitis · Neuritis

\section{INTRODUCTION}

Capture and fattening of southern bluefin tuna (SBT) for the Japanese sashimi market is a recent innovation in Australia and is entirely localised to Port Lincoln in South Australia. Wild SBT in the range of 15 to $35 \mathrm{~kg}$ bodyweight are captured, usually by purseseine netting in the southern summer/fall (December to May) and placed in sea-cages where they are fed frozen 'bait' fish, predominantly pilchards Sardinops spp.

Once accustomed to captivity, the fish fatten quickly and harvesting commences within 3 mo of capture with all fish being removed from the sea-cages prior to the intake of the next batch of tuna.

Individual, market-ready fish have a value of \$A1000-2000 and the total value of the industry has increased from $\$ A 1.8 \mathrm{~m}$ in $1991-92$ to $\$ A 64.0 \mathrm{~m}$ in $1994-95$.

Apart from immediate and delayed mortalities associated with capture and towing in special cages, SBT have proven to be very robust and disease problems

•E-mail: barry.munday@utas.edu.au were minimal in 1991 and 1992. However, in the winter/spring (June-October) of 1993 significant mortalities were reported in association with unusual clinical signs. This previously undescribed syndrome is the subject of this report.

\section{MATERIAL AND METHODS}

Fish. Clinically affected Thunnus maccoyii (Castelnau), colloquially termed 'swimmers', were all captive and had been held for periods of 3 to $8 \mathrm{mo}$. Appropriate samples for comparative purposes were collected from unaffected captive tuna.

Clinical parameters. Information on the proportion of fish affected and clinical signs were provided by farm operators. Clinically affected fish were also observed by some of the authors.

Clinical pathology. Blood samples from affected and normal tuna were collected by cardiac puncture into plain and EDTA and fluoride-oxalate treated tubes.

Haematocrits and differential leucocyte counts were undertaken at the Tuna Boat Owners Association laboratory at Port Lincoln. 
Blood samples were submitted to Veterinary Pathology Services, Adelaide, for estimation of haemoglobin and glucose in whole blood, and creatine phosphokinase, alanine aminotransferase, protein, calcium, magnesium, sodium, chloride, potassium and cortisol in serum.

Results for affected and unaffected fish were compared for significant differences using the Student's t-test.

Macroscopic and microscopic pathology. Most affected fish were collected alive although a small number of presumptive 'swimmers' were retrieved within $6 \mathrm{~h}$ of death from the bottom of the net pens. Because affected fish still had a monetary value, full necropsies were only undertaken on a small number. The other diseased tuna and all normal fish were examined by a modified necropsy technique which permitted collection of selected samples. Some difficulty was experienced in obtaining the tissues of choice (central nervous system) because in fish for the sashimi market the brain and spinal cord are immediately destroyed by trephining a hole in the skull and passing a wire down the spinal canal.

Minimal samples for histological examination were olfactory rosettes, olfactory nerves and brain. Additional highly desirable samples were spinal cord and optic nerves. Other samples taken depending on circumstances were gills, heart, liver, pancreas, spleen, head and tail kidney and skeletal muscle.

Tissues were fixed in $10 \%$ formal saline then trimmed and embedded in paraffin wax, before sectioning at $5 \mu \mathrm{m}$ and staining with haematoxylin and eosin.

Parasitology. Live ciliates were observed in wet preparations of cerebrospinal fluid and brain using normal saline or seawater as diluent where necessary. Examination was at 100 and $400 \times$ using bright-field, phase-contrast and Nomarski interference-contrast illumination.

Culture of these protozoans from central nervous tissues was achieved using brain heart infusion broth diluted $1 / 10 \mathrm{v} / \mathrm{v}$ with sterile $0.2 \mu \mathrm{m}$ filtered seawater. For each $1 \mathrm{l}$ of this medium $25 \mu \mathrm{l}$ of lysed blood and $25 \mu$ of vitamin solution (Accomin, Cyanamid) was added. Marine environmental bacteria were added to the broth to provide a food source and these were encouraged to grow by leaving the culture at room temperature overnight before reducing the temperature to $4^{\circ} \mathrm{C}$ to prevent bacterial overgrowth (Watts 1995).

Axenic culture of central nervous tissue taken aseptically was performed using a modified marine axenic medium (Messick \& Small 1996).

Live ciliates were examined unstained and stained with methyl-green pyronin to record vital characteristics and patterns of motility. Clinical isolates and cul- tured ciliates were fixed in Bouin's fluid, washed in distilled water and subsequently stained by silver proteinate (protargol) impregnation using standard techniques (Foissner 1991). Stained ciliates were examined by light microscopy, measured using a calibrated eyepiece graticule, drawn with the aid of a camera lucida and photographed.

\section{RESULTS}

\section{Epidemiological information}

Clinical cases of 'swimmer' syndrome have only been reported between May and November when water temperatures fall below $18^{\circ} \mathrm{C}$ with most cases occurring at temperatures below $15^{\circ} \mathrm{C}$. In 1993 the number of affected tuna was reported as 5 to $10 \%$ of the fish remaining after June of that year. Mortalities in 1994 and 1995 were reportedly lower, but, because of the high value of individual fish, were still of concern.

\section{Clinical signs}

Affected tuna were in good condition and usually died within 2 to $8 \mathrm{~h}$ of being first detected, although the occasional fish survived for 24 to $72 \mathrm{~h}$. Typically, the fish came to the surface, turned light blue and swam vigorously around the cage. Eventually, the fish ceased compulsive swimming and exhibited short bursts of forward motion with their heads out of water, followed by periods of sinking, before once again coming to the surface and then repeating the process. Finally, the fish sank and died at the bottom of the netpen.

\section{Clinical pathology}

Significant variations from presumptive normal values were found for serum protein, magnesium, sodium, chloride, cortisol (elevated) and potassium (lowered) and blood glucose (elevated). These alterations were considered to be related to general stress resulting from the disease process and were of no direct diagnostic value. Mean values for normal and affected fish are shown in Table 1.

\section{Macroscopic lesions}

Specific changes have been restricted to the olfactory rosettes and brain. In affected fish the olfactory rosettes were frequently darkened and the brain exhibited variable degrees of softening/liquefaction. 
Table 1. Thunnus macroyiu. Clinical pathology results for normal and diseased (swimmer) tuna. Significant differences shown by ${ }^{\prime} p<0.01, \cdot p<0.001$

\begin{tabular}{|c|c|c|c|c|}
\hline $\begin{array}{l}\text { Parameter } \\
\text { (unit) }\end{array}$ & $\begin{array}{c}\text { Normal } \\
\text { Mean }(\mathrm{SE})\end{array}$ & $\mathrm{n}$ & $\begin{array}{l}\text { Swimmer } \\
\text { Mean (SE) }\end{array}$ & $\mathrm{n}$ \\
\hline Haemaglobin $\left(\mathrm{g} \mathrm{l}^{-1}\right)$ & $15.94(0.26)$ & 10 & $16.23(0.25)$ & 4 \\
\hline Haematocrit $(\%)$ & $47.40(0.78)$ & 10 & $50.00(1.11)$ & 4 \\
\hline Creatine phosphokinase $\left(\mathrm{U}^{-1}\right)$ & $629.90(136.56)$ & 10 & $568.20(99.42)$ & 10 \\
\hline Alanine aminotransferase $\left(\mathrm{U} \mathrm{l}^{-1}\right)$ & $13.00(5.82)$ & 10 & $3.60(0.35)$ & 10 \\
\hline Protein $\left(\mathrm{g} \mathrm{l}^{-1}\right)$ & $53.30(0.78)$ & 10 & $60.10(0.89)^{\circ}$ & 10 \\
\hline Magnesium (mmol l-1) & $0.84(0.01)$ & 10 & $1.92(0.21)^{\circ}$ & 10 \\
\hline Sodium $\left(\mathrm{mmol} \mathrm{l}^{-1}\right)$ & $192.10(0.90)$ & 10 & $206.60(2.00)^{\bullet}$ & 10 \\
\hline Potassium $\left(\mathrm{mmol}^{-1}\right)$ & $4.33(0.21)$ & 10 & $2.28(0.16)^{\cdots}$ & 10 \\
\hline Chloride $\left(\mathrm{mmol} \mathrm{l}^{-1}\right)$ & $148.90(0.75)$ & 10 & $177.60(1.27)^{\cdots}$ & 10 \\
\hline Calcium $\left(\mathrm{mmol} \mathrm{l}^{-1}\right)$ & $3.29(0.03)$ & 10 & $3.51(0.05)$ & 10 \\
\hline Cortisol (nmol l-1 ${ }^{-1}$ & $15.70(5.48)$ & 10 & $1195.50(17.57)^{\cdots}$ & 10 \\
\hline Glucose $\left(\mathrm{mmol} \mathrm{l}^{-1}\right)$ & $6.94(0.27)$ & 10 & $14.31(0.61)^{\cdots}$ & 10 \\
\hline Heterophils (\% range) & $4.61-11.26$ & 10 & $1.29-9.15$ & 10 \\
\hline Monocytes (\% range) & $1.19-5.92$ & 10 & $2.58-3.27$ & 10 \\
\hline Lymphocytes (\% range) & $48.68-51.66$ & 10 & $56.86-61.94$ & 10 \\
\hline Eosinophils (\% range) & $2.63-7.29$ & 10 & $0-3.92$ & 10 \\
\hline Thrombocytes ( $\%$ range) & $17.26-38.16$ & 10 & $26.80-34.19$ & 10 \\
\hline
\end{tabular}

\section{Microscopic lesions}

Lesions of the brain parenchyma were restricted to the forebrain where pyriform organisms were found in varying numbers in brain tissue. Peripheral cilia were detected in a few organisms and a macronucleus was visible (Fig. 1). In some lesions there were numerous ciliates containing erythrocytes and food-granules present in areas of liquefaction (Fig. 2). At the other extreme, organisms were rare and they contained fewer food granules and there was no liquefaction of the brain parenchyma. In both instances, there was no host response apart from the presence of compound granular corpuscles in areas of liquefaction.

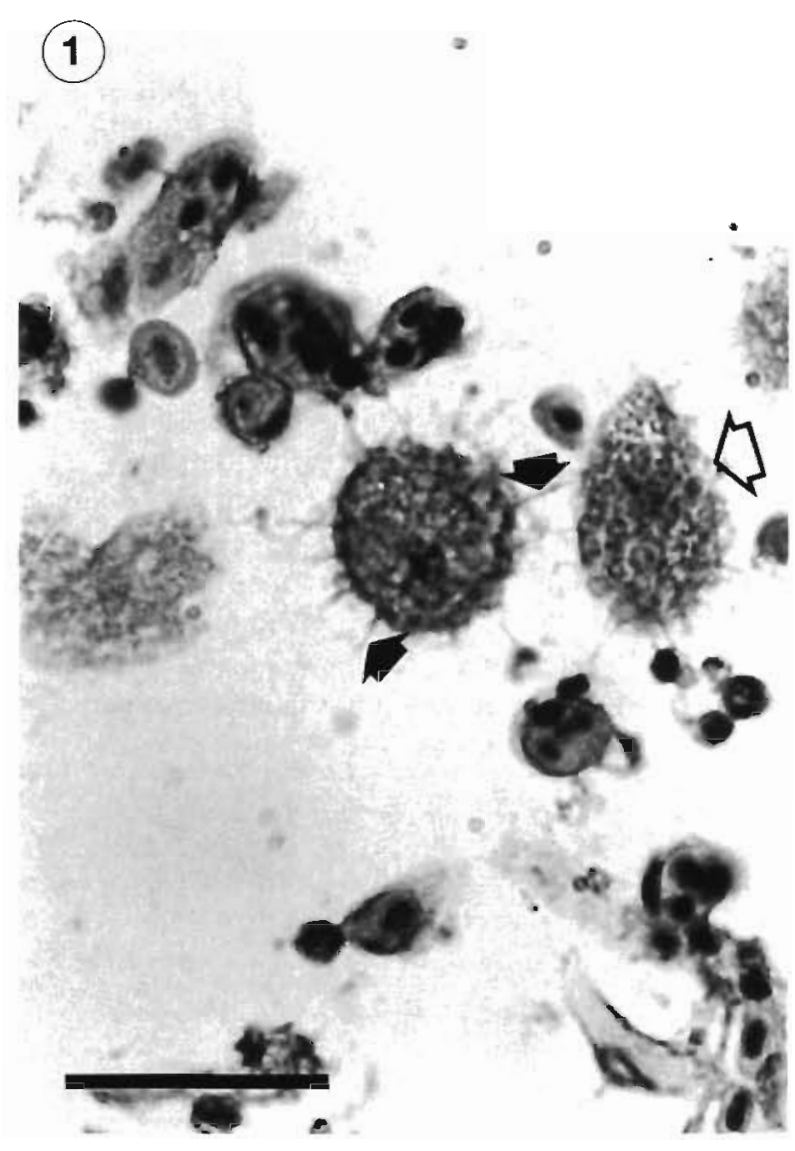

Fig. 1. Uronema nigricans in brain of southern bluefin tuna Thunnus maccoyii. Note tear drop shape in longitudinal section (open arrow) and presence of cilia in parasite cut in cross section (solid arrows). H\&E. Scale bar $=25 \mu \mathrm{m}$

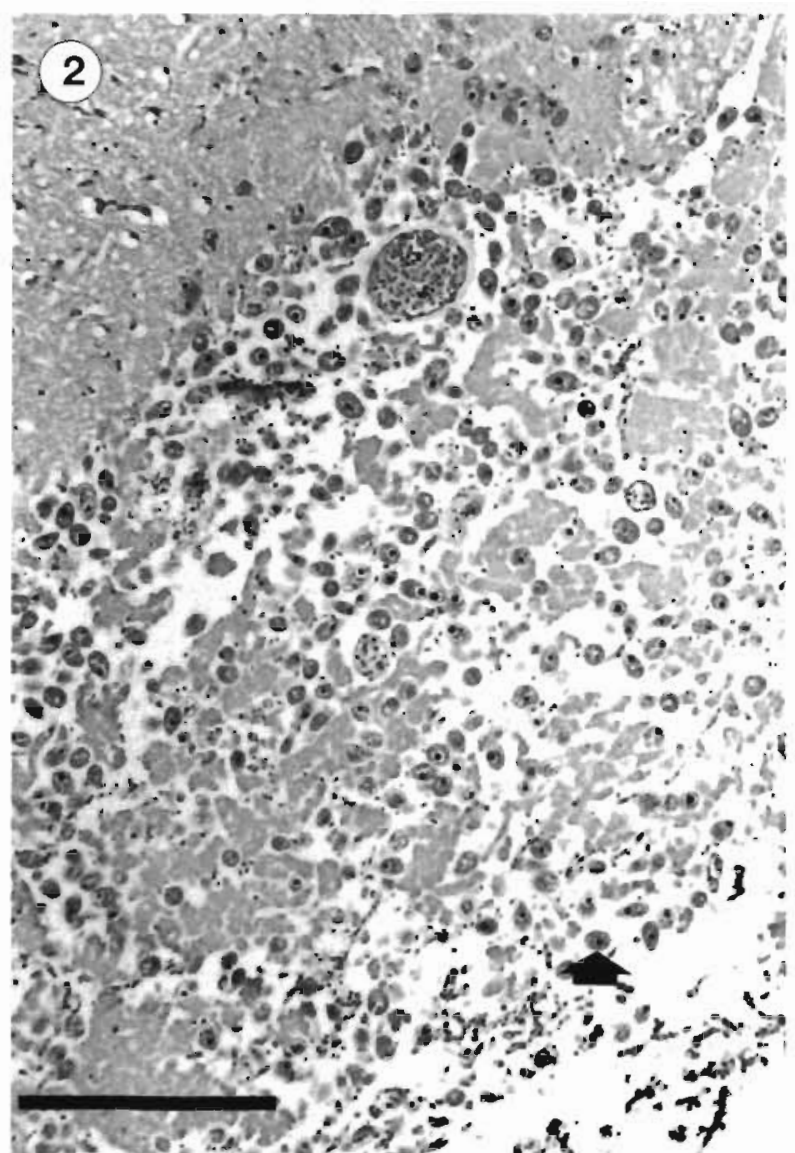

Fig. 2. Area of liquefactive necrosis in forebrain of bluefin tuna Thunnus maccoyi. Note numerous scuticociliates (solid arrow). H\&E. Scale bar $=250 \mu \mathrm{m}$ 
Contrary to the situation in other fish (Ferguson 1989) lateral ventricles were present in the brain and there frequently was a mild to moderate, lymphocytic ependymitis. In some instances haemorrhage was associated with the parasitic invasion. Similar lesions were also found in the third ventricle

Focal meningitis was a common finding. This varied from a mild lymphocytic invasion accompanied by oedema to thickening of the meninges with associated lymphocytic reaction. Variable numbers of ciliates were consistently found in these lesions and usually they contained relatively few food granules (Fig. 3).

Lesions were consistently found in the olfactory nerves. The most common finding was the presence of linear necrosis often with accompanying lymphocytic infiltration. Ciliates were usually associated with the lesions (Fig. 4). In some instances focal zones of necrosis led to partial or even complete destruction of the nerve-in the latter instance there was thrombosis of blood vessels and invasion by macrophages. Inflammatory lesions were consistently found in the perineural tissues. This inflammation was usually lymphocytic in nature but in one, apparently longerstanding lesion, there were macrophages and eosinophilic granule cells in the thickened, fibrotic tissues (Fig. 5).

In the olfactory rosette specific lesions were only found in the axis. In those instances where there was significant necrosis, ciliates were present in moderate numbers. Otherwise there was an inflammatory response consisting of oedema, lymphocytes, plasma cells, macrophages and eosinophilic granule cells and only a few, scattered ciliates (Fig. 6).

\section{Parasitology}

\section{Culture}

The ciliate grew readily in brain heart infusion with marine bacteria, but care was needed to ensure that bacterial overgrowth did not occur and lead to elimination of the protozoans. Axenic organisms grew more slowly (in the order of approximately $25 \%$ the rate of non-axenic culures)

\section{Live observation}

Numerous ciliates were detected in cerebrospinal fluid recovered from the brain cavities and olfactory nerves of infected tuna. The ciliates ranged from 22 to $32 \mu \mathrm{m}$ in length by 12 to $18 \mu \mathrm{m}$ in width and were pyriform in shape with a slightly flattened and oblique anterior margin (Fig. 7).

The ciliates were uniformly covered with short somatic cilia except for the anterior pole which remained naked. All ciliates possessed a prominent caudal cilium approximately twice the length of the somatic cilia. The oral ciliature was inconspicuous in unstained preparations and was located in a slight subapical depression extending backwards to the equator. Supravital staining with methyl-green pyronin revealed the presence of a large spherical macronucleus and a small micronucleus located in the anterior to middle portion of the cell. The ciliate pellicle contained numerous trichocysts distributed over the entire surface. Ciliates recovered from tuna were robust and granular in appearance due to the presence of numerous pale-green and red food vacuoles located mainly in the posterior half of the body (Fig. 8a). Bilobed lamellar vesicles were also occasionally observed in the cytoplasm. The ciliates contained a single translucent contractile vacuole located near the posterior pole. Cultured ciliates were more slender in appearance and usually contained fewer food vacuoles (Fig. 8b). The ciliate pellicle was colourless and ridged between somatic kineties (Fig. 8a, b). The ciliates were highly motile in wet mounts and they exhibited a smooth swimming motion while slowly rotating about their long axes in a corkscrew pattern. The ciliates were somewhat elastic in shape and were observed to distend and stretch their way through small gaps. They were actively bactivorous and stopped frequently to feed on bacterial masses. They were also observed to congregate and browse over particulate material but it is not known whether this represented histophagous behaviour. Cyst formation was not observed even when wet mounts became depleted of tissue or dried out.

\section{Silver impregnation}

The ciliates readily stained with protargol revealing details of their oral and somatic ciliature (Figs. 8 to 10 ).

Figs. 3 to 6. Thunnus maccoyii infected with Uronema nigricans. Fig. 3. Meningitis of tuna forebrain (open arrow) associated with numerous $U$. nigricans. H\&E. Scale bar $=250 \mu \mathrm{m}$. Fig. 4. Olfactory neuritis associated with U. nigricans (small solid arrows). H\&E. Scale bar $=250 \mu \mathrm{m}$. Fig. 5. Marked olfactory perineuritis in bluefin tuna. A few $U$. nigricans are present within the nerve tissue adjacent to the inflammatory reaction (solid arrow). H\&E. Scale bar $=250 \mu \mathrm{m}$. Fig. 6 . Inflammatory response to scuticociliates (small solid arrows) in the olfactory rosette of a bluefin tuna. Note branch of olfactory nerve (large solid arrow). H\&E. Scale $\mathrm{bar}=250 \mu \mathrm{m}$ 


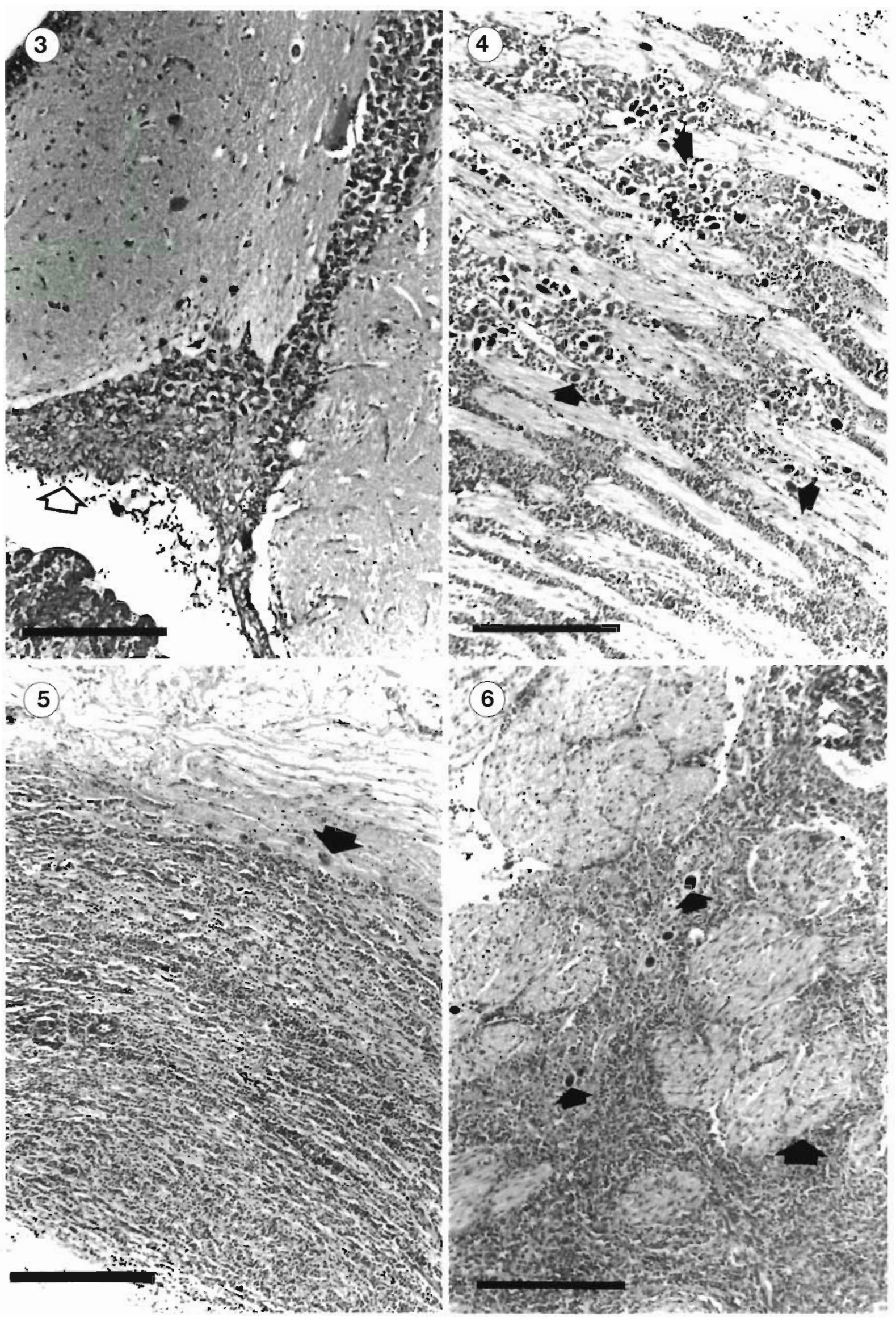




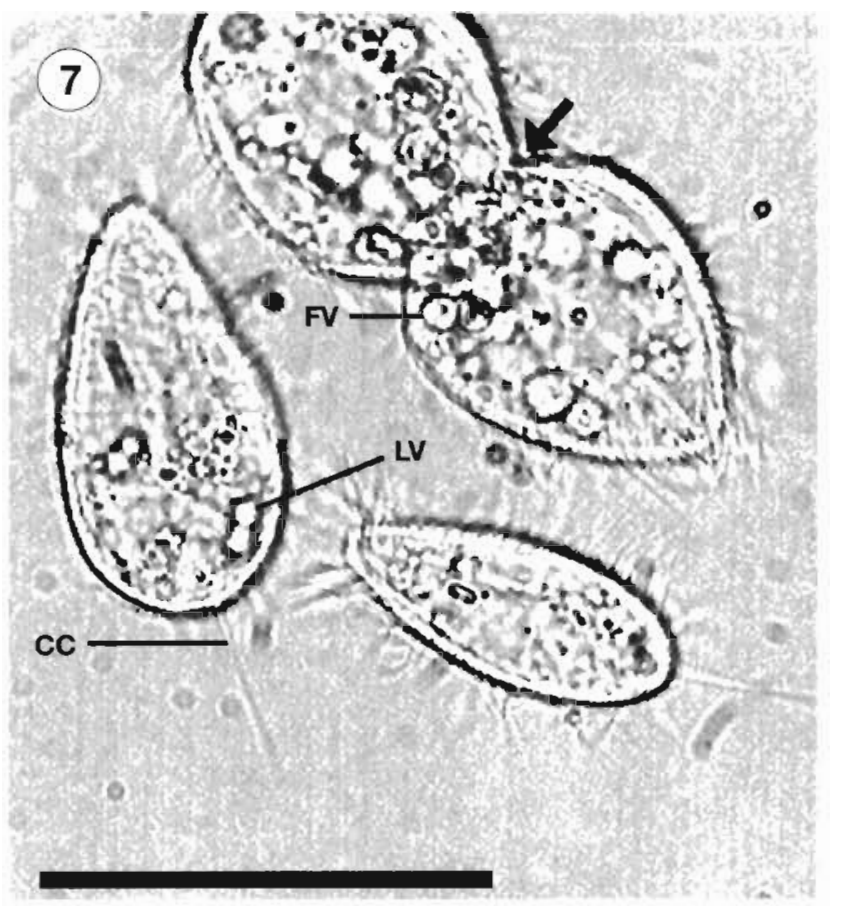

Fig. 7. Uronema nigricans in Thunnus maccoyii cerebrospinal fluid. Live organisms of variable size in a wet preparation. Note a dividing cell (arrow) containing numerous food vacuoles, one of which is labelled (FV). A lamellar vesicle (LV) is indicated in the cell on the left and the caudal cilium (CC) is clearly visible. Scale bar $=25 \mu \mathrm{m}$

The first membranelle did not appear to be ciliated. Individual kinetosomes were not discernible in the third membranelle or the undulating membrane. The former was triangular in shape and the latter was elongate, beginning adjacent to the second membranelle and curving posteriorly around the cytostome. A nonciliated scuticum consisting of 3 to 5 kinetosomes was located below the cytostome in line with the undulating membrane. A cytoproct was visible as a faint irregular line located posterior to the scuticum. The ciliates contained a single ovoid macronucleus measuring on average $7.1 \mu \mathrm{m}$ in diameter located around the middle of the cell next to a small ovoid micronucleus measur-
Their key morphometric characteristics are given in Table 2. Fixed and stained ciliates were variable in size ranging from 19.8 to $34.0 \mu \mathrm{m}$ in length by 7.1 to $20.0 \mu \mathrm{m}$ in width. They contained distinctive somatic ciliature consisting of 12 to 14 longitudinal kineties arranged in meridional rows. The first and last kineties curved around the buccal apparatus and all meridians terminated before reaching the anterior or posterior poles (Fig. 8c). The first kinety was slightly shorter than the remainder and terminated near the contractile vacuole pore. Each kinety contained 24 to 30 kinetosomes which were paired in the anterior two-thirds of the cell. Only the posterior 2 to 4 kinetids were monokinetids whereas the remainder were dikinetids. The somatic cilia measured on average $3.2 \mu \mathrm{m}$ in length and the caudal cilium $7.7 \mu \mathrm{m}$ in length (Table 1 ). The caudal cilium arose from a kinetosome located between 2 parasomal sacs located at the posterior pole (Fig. 8c). The oral ciliary field was always located in the anterior half of the body, beginning on average $3.1 \mu \mathrm{m}$ from the anterior pole and extending $11.2 \mu \mathrm{m}$ backwards to the equator. The oral apparatus consisted of an elongate paroral (undulating) membrane on the right and 3 shorter membranelles on the left (Fig. 8c). The first membranelle appeared as a single row of 4 kinetosomes and the second membranelle as a double row of 4 kinetosomes.
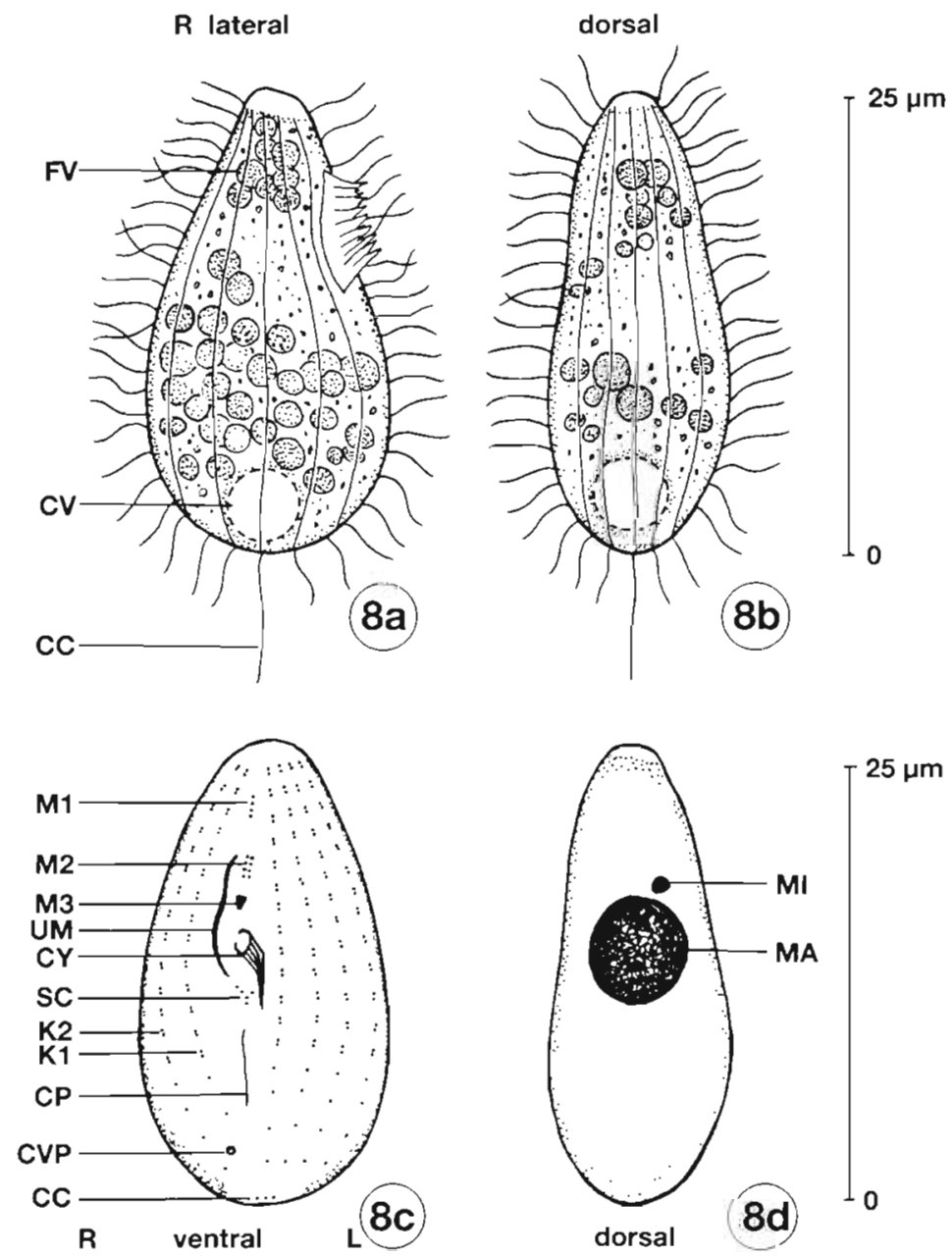
Table 2. Uronema nigricans. Morphometric characterization of scuticociliate recovered from the forebrain of southern bluefin tuna Thunnus maccoyi. SD: standard deviation; CV: coefficient of variation; Min: minimum; Max: maximum; n: number of observations

\begin{tabular}{|c|c|c|c|c|c|c|}
\hline Character & Mean & $\mathrm{SD}$ & $\mathrm{CV}$ & Min & $\operatorname{Max}$ & $\mathrm{n}$ \\
\hline \multicolumn{7}{|l|}{ Body dimensions } \\
\hline Length ( $\mu \mathrm{m})$ & 26.1 & 3.59 & 13.8 & 19.8 & 34.0 & 20 \\
\hline Width $(\mu \mathrm{m})$ & 11.9 & 3.62 & 30.3 & 7.1 & 20.0 & 20 \\
\hline \multicolumn{7}{|l|}{ Nuclei } \\
\hline Macronucleus diameter ( $\mu \mathrm{m})$ & 7.1 & 1.83 & 25.7 & 4.2 & 10.4 & 20 \\
\hline Micronucleus diameter ( $\mu \mathrm{m})$ & 1.1 & 0.29 & 26.8 & 0.6 & 1.7 & 20 \\
\hline \multicolumn{7}{|l|}{ Somatic ciliature } \\
\hline Total number of kineties & 12.4 & 0.84 & 6.8 & 12 & 14 & 10 \\
\hline Length of somatic cilia ( $\mu \mathrm{m})$ & 3.2 & 0.60 & 18.5 & 2.8 & 5.0 & 14 \\
\hline Length of caudal cilium ( $\mu \mathrm{m})$ & 7.7 & 0.31 & 4.1 & 7.1 & 8.2 & 10 \\
\hline \multicolumn{7}{|l|}{ Oral ciliature } \\
\hline Distance from apex to oral ciliary field $(\mu \mathrm{m})$ & 3.1 & 0.73 & 23.2 & 2.1 & 5.2 & 18 \\
\hline Length of oral ciliary field $(\mu \mathrm{m})$ & 11.2 & 2.14 & 19.1 & 7.2 & 16.5 & 17 \\
\hline Length of undulating membrane $(\mu \mathrm{m})$ & 7.7 & 1.63 & 21.1 & 4.9 & 10.4 & 17 \\
\hline Length of first membranelle, $\mathrm{M} 1(\mu \mathrm{m})$ & 1.7 & 0.40 & 23.8 & 1.0 & 2.4 & 18 \\
\hline Length of second membranelle, M2 $(\mu \mathrm{m})$ & 2.2 & 0.48 & 21.6 & 1.4 & 3.1 & 18 \\
\hline Length of third membranelle, M3 ( $\mu \mathrm{m})$ & 0.9 & 0.20 & 22.1 & 0.5 & 1.2 & 17 \\
\hline
\end{tabular}

ing $1.1 \mu \mathrm{m}$ in diameter (Fig. 8d). On the basis of their morphological characteristics (summarized by Thompson \& Evans 1968, Dragesco \& Dragesco-Kernéis 1986 , Foissner et al. 1994), the ciliates were identified as belonging to the species Uronema nigricans (Mueller 1786) Florentin 1901.

\section{DISCUSSION}

Uronema-like scuticociliates, previously regarded as being environmental scavengers, are increasingly being recognised as important opportunistic pathogens of marine fish.
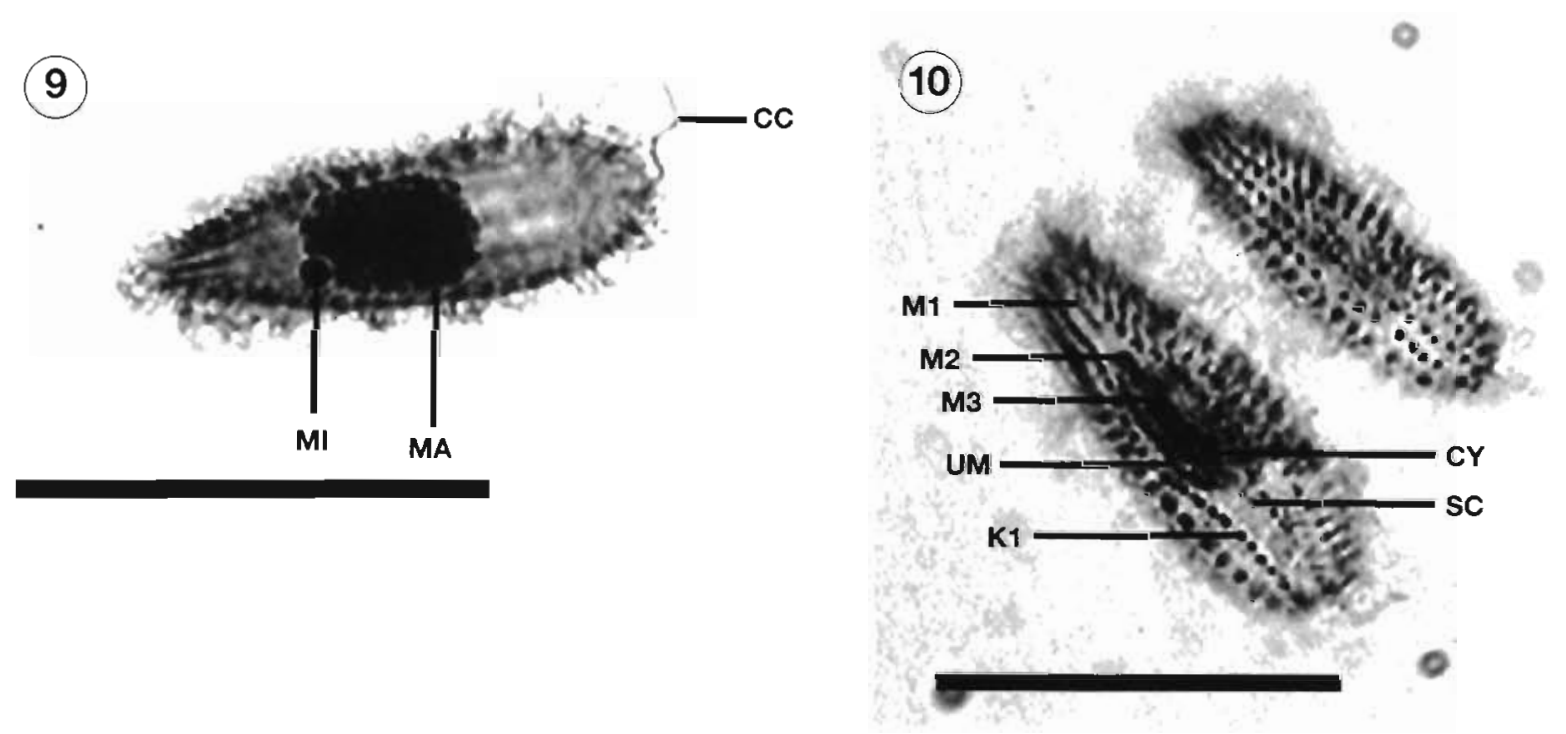

Figs. 8 to 10 (facing page and above). Uronema nigricans from southern bluefin tuna Thunnus maccoyii. Fig. 8. (a) Right lateral view of robust ciliate recovered from forebrain. (b) Dorsal view of slender ciliate following in vitro culture. (c) Ventral view of protargol impregnated ciliate showing oral and somatic infraciliature. (d) Dorsal view of silver stained ciliate showing nuclei. Scale bars $=25 \mu \mathrm{m}$. CC: caudal cilium; CP: cytoproct; CV: contractile vacuole; CVP: contractile vacuole pores; CY: cytostome; FV: food vacuoles; K1: first kinety; K2: second kinety; L: left side; MA: macronucleus; MI: micronucleus; M1, M2, M3: first, second and third membranelles; R: right side; UM: undulating membrane; SC: scuticum. Fig. 9. A protargol-stained cell showing the micronucleus (MI), macronucleus (MA) and caudal cilium (CC). Scale bar $=25 \mu \mathrm{m}$. Fig. 10. Protargol-stained cells. Ventral view demonstrates membranelles 1, 2 and 3 (M1, M2, M3). The undulating, or paroral membrane (UM), cytoproct (CY) and scuticum (SC) are also visible. The first kinety is indicated (K1). Scale bar $=25 \mu \mathrm{m}$ 
In finfish, they have been implicated in disease of all growth phases. Munday (1996) reported generalised infections leading to severe mortalities in larval marine fish. Heavy mortalities due to histophagous ciliates were reported in juvenile turbot Scopthalmus maximus by Dykova \& Figueras (1994) and significant disease has been reported in flounder (Yoshinaga \& Nakazoe 1993) and sea bass (Dragesco et al. 1995). Subadult and adult fish affected by scuticociliasis usually suffer from a parasitic myositis (Cheung et al. 1980, Bassleer 1983, Munday 1996), but seahorses may be more affected by inflammatory lesions of the skin and gill (Cheung et al. 1980, Munday 1996). However, the type of pathology found in SBT appears to be unique except for a single case in a yellowtail kingfish Seriola lalandi captured in a tuna cage (Rough unpubl.).

Scuticociliates have also been associated with clinical disease in crabs, lobsters and prawns (Morado \& Small 1995, Cawthorn et al. 1996) and clam Venecrupis sp. larvae (G. Maguire pers. comm.) thus indicating the great potential importance of these pathogens in marine aquaculture.

In many instances the protozoans associated with particular outbreaks have not been fully identified. Cheung et al. (1980) classified the organism present in aquarium fish as Uronema marinum. The ciliates present in SBT were clearly hymenostomes with welldefined oral and somatic ciliature, the former comprising an undulating membrane and 3 membranelles. They possessed a distinctive scuticum located below the oral ciliary field and were readily identified as scuticociliates (Corliss 1979). They belonged to the suborder Philasterina because their undulating membranes were shorter than the other oral structures and the membranes were not reinforced by ribbed walls (Small \& Lynn 1985). Of the 12 constituent families, the ciliates belonged to the family Uronematidae because the undulating membrane and 3 membranelles were aligned with the long axis of the body and the anterior pole was nonciliated and flattened. The ciliates were differentiated from 5 other genera and assigned to the genus Uronema on the basis of the location of the cytostome which was always anterior to the equator (Small \& Lynn 1985).

Over 25 Uronema spp. have previously been described, all originally being reported as free-living organisms in freshwater or marine habitats. Of these, only 10 species have been described (or redescribed) using silver impregnation techniques (cf. Pérez-Uz \& Song 1995). The morphological characteristics of the ciliates recovered from the tuna conformed to those previously reported for the species $U$. nigricans by Thompson \& Evans (1968), Dragesco \& DragescoKernéis (1986), Song (1991), Foissner et al. (1994) and Pérez-Uz \& Song (1995). They could be differentiated from all other Uronema spp. on the basis of their size, number of somatic kineties, alignment of caudal cilium complex, position of contractile vacuole, length and position of oral apparatus and location of cytostome. They were most similar to $U$. marinum except that the latter were larger in size, contained more somatic kineties and the oral apparatus was located further from the anterior pole (Thompson 1964, Dragesco \& Dragesco-Kernéis 1986, Coppellotti 1990, Foissner et al. 1994). Several authors have previously suggested that $U$. nigricans and $U$. marinum be synonymized due to their superficial similarities (e.g. Hoare 1927, Kahl 1931) whereas others have suggested that they be retained as separate species on the basis of their occurrence in freshwater and marine habitats respectively (Thompson \& Evans 1968). However, U. nigricans has been recorded from both freshwater and marine habitats and various isolates have exhibited good growth in brackish and seawater (Pérez-Uz 1995). Pending further characterization studies, we regard them to be separate species on the basis of their morphological differences and do not consider them to be restricted to specific habitats. The ciliates detected in the tuna were therefore identified as U. nigricans (Mueller 1786) Florentin 1901.

Presumptive diagnosis of the disease in SBT can be made by examining wet preparations of CSF and brain. However, although a fluorescent antibody test has been developed for cultured and environmental organisms (Watts 1995), this is not suitable for clinical material because of autofluorescence of host tissues. Definitive diagnosis can be made by microscopic examination of histological slides of nervous tissues. As clinical pathology only reflects general stress and perturbed osmoregulation, it is of no specific diagnostic value.

The proposed pathogenesis of the disease in SBT is that Uronema nigricans initially parasitizes the olfactory rosette at which stage the host mounts a vigorous inflammatory response. If the host response is inadequate, the ciliate then invades branches of the olfactory nerve present in the axis of the olfactory rosette. Even though there is still some host response to invasion of the olfactory nerve the migration of $U$. nigricans is probably then inexorable, ending in invasion of the brain, which causes locomotor dysfunction and, ultimately, death.

Epidemiological factors which may be implicated in the initiation of the disease in SBT are water temperature and host immune status.

The 'swimmer' syndrome has not occurred when water temperatures have exceeded $18^{\circ} \mathrm{C}$. SBT maintain a body temperature of about $24^{\circ} \mathrm{C}$, even in much colder water (A. Smart pers. comm.), so it is possible that the parasite, which would be expected to have an 
optimum growth temperature of about $25^{\circ} \mathrm{C}$ (Parker 1976), would be preferentially attracted to the fish under conditions of relatively low water temperatures $\left(<18^{\circ} \mathrm{C}\right)$.

Studies undertaken by Fitz-Gerald \& Bremner (1997) have shown that the pilchards fed to captive SBT are highly oxidised. When this is taken in the context of the work of Obach \& Baudin Laurencin (1992), who demonstrated immunosuppression in turbot fed a diet high in oxidised oils, it is likely that the tuna become immunocompromised as a result of the type of diet they receive. Whether or not other factors, such as the stress of captivity, could also affect immunocompetence is more difficult to decide. The immune status of captive SBT is now under investigation by the authors.

Attempts to control the disease in SBT will focus on improving the environmental conditions and optimising the immune system of the tuna by dietary manipulations and/or the addition of immunomodulators to the diet.

Acknowledgements. Helpful discussion has been provided by Drs R. Adlard and C. Burke. Mr S. Clarke provided administrative support and Dr F. Roubal assisted with field investigations. One of the authors (K.R.) was partially funded by a Teaching Company Scheme Grant provided by the Department of Industry Technology and Regional Development.

\section{LITERATURE CITED}

Bassleer G (1983) Uronema marinum, a new and common parasite on tropical saltwater fishes. Freshwater Mar Aquarium 6:78-81

Cawthorn RJ, Lynn DH, Despres B, MacMillan R, Maloney R, Loughlin M. Bayer R (1996) Description of Anophryoides haemophila n. sp. (Scuticociliatida: Orchitophryidae), a pathogen of American lobsters Homarus americanus. Dis Aquat Org 24:143-148

Cheung PJ, Nigrelli RF, Ruggieri GD (1980) Studies on the morphology of Uronema marinum Dujardin (Ciliatea: Uronematidae) with a description of the histopathology of the infection in marine fishes. J Fish Dis 3:295-303

Coppellotti O (1990) Description of Uronema marinum (Ciliophora, Scuticociliatida) from the Antarctica and observations on the nuclear events in conjugation. Polar Biol 10 $365-371$

Corliss JO (1979) The ciliated protozoa. Pergamon Press, Oxford

Dragesco A, Dragesco J, Coste F, Gasc C, Romestand B, Raymond JC, Bouix G (1995) Philasterides dicentrarchi, n. sp., (Ciliophora, Scuticociliatida), a histophagous opportunistic parasite of Dicentrarchus labrax (Linnaeus, 1758), a reared marine fish. Eur J Protistol 31:327-340

Dragesco J, Dragesco-Kernéis A (1986) Ciliés libres de l'Afrique intertropicale. Collection Faune Tropicale No. 26. Institut Français de Recherche Scientifique pour le Développement en Coopération, Paris

Dykova I, Figueras A (1994) Histopathological changes in tur- bot Scophthalmus maximus due to a histophagous ciliate. Dis Aquat Org 18:5-9

Ferguson HW (1989) Systemic pathology of fish. Iowa State University Press, Ames

Fitz-Gerald C. Bremner A (1997) Improving the stability and nutritional value of frozen small fish for tuna feed. J Food Prod Technol (in press)

Foissner W (1991) Basic light and scanning electron microscopic methods for taxonomic studies of ciliated protozoa. Eur J Protistol 27:313-330

Foissner W, Berger $H$, Kohmann F (1994) Taxonomische und ökologische Revision der Ciliaten des Saprobiensystems. Band III: Hymenostomata, Prostomatida, Nassulida. Informationsberichte des Bayer. Landesamtes für Wasserwirtschaft, 1/94, München

Hoare CA (1927) Studies on coprozoic ciliates. Parasitology 19:154-222

Kahl A (1931) Urtiere oder Protozod I: Wimptiere oder Ciliata (Infusoria) 2. Tierwelt Dtl 21:181-398

Messick GA, Small EB (1996) Mesanophrys chesapeakensis n. sp., a histophagous ciliate in the blue crab, Callinectes sapidus, and associated histopathology. Invertebr Biol 115: $1-12$

Morado JF, Small EB (1995) Ciliate parasites and diseases of Crustacea: a review. Rev Fish Sci 3:275-354

Munday BL (1996) Infectious diseases of finfish. In: Bryden D (ed) Fish health workshop. Post Graduate Foundation in Veterinary Science, University of Sydney, Sydney, p $81-123$

Obach A, Baudin Laurencin F (1992) Effects of dietary oxidised fish oil and deficiency of anti-oxidants on the immune response of the turbot, Scophthalmus maximus. Aquaculture 107:221-228

Parker JG (1976) Cultural characteristics of the marine ciliated protozoan Uronema marinum Dujardin. I Exp Mar Biol Ecol 24:213-226

Pérez-Uz B (1995) Growth rate variability in geographically diverse clones of Uronema (Ciliophora: Scuticociliatida) FEMS (Fed Eur Microbiol Soc) Microbiol Ecol 16:193-204

Pérez-Uz B, Song W (1995) Uronema gallicum sp. n. (Protozoa: Ciliophora) a new marine scuticociliate from the coastal area of Calais. Acta Protozool 34:143-149

Small EB, Lynn DH (1985) Phylum Ciliophora Doflein, 1901. In: Lee JJ, Hutner SH, Bovee EC (eds) An illustrated guide to the Protozoa. Society of Protozoologists, Lawrence, KS, p 393-575

Song W (1991) Morphology and morphogenesis of the freshwater scuticociliate Uronema nigricans (Mueller, 1786). Acta Zool Sin 37:233-243 (in Chinese with English summary)

Thompson JC (1964) A redescription of Uronema marinum, and a proposed new family Uronematidae. VA J Sci 149 $80-87$

Thompson JC, Evans FR (1968) A redescription of Uronema nigricans. J Protozool 15:369-374

Watts $M$ (1995) The development of a fluorescent antibody stain to identify a Uronema sp. (Ciliophora: Scuticociliatida) implicated in fatal encephalitis in farmed tuna (Thunnus maccoyii). Honours thesis, University of Tasmania, Launceston

Yoshinaga T, Nakazoe $J$ (1993) Isolation and in vitro cultivation of an unidentified ciliate causing scuticociliosis in Japanese flounder (Paralichthys olivaceus). Gyobyo Kenkyu 28:131-134

Manuscript received: May 11, 1996 Revised version accepted: April 11, 1997 